\title{
Words as Powerful Weapons: Dysphemism in Trump's Covid-19 Speeches
}

\author{
SAMEER NASER OLIMAT \\ English Language Department \\ Salt Faculty of Human Sciences \\ Al-Balqa Applied University, Jordan \\ sameer.olimat@bau.edu.jo
}

\begin{abstract}
Covid-19 pandemic constitutes the greatest threat to the worldwide population and countries nowadays. Donald Trump, the president of the greatest country in the world, has frequently received heavy criticism as a result of his language use in the period of Covid-19. Therefore, the present paper examines dysphemistic expressions used in Trump's discourse on Covid-19. A sample of dysphemistic examples adopted in Trump's daily speeches in a crucial week of $11^{\text {th }}$ till $18^{\text {th }}$ of March 2020 was analysed. The researcher relied on the Critical-political Discourse Analysis by Van Dijk (1997; 2001), Conceptual Metaphor theory by Lakoff and Johnson (1980), and the concept of dysphemism by Allan and Burridge (2006). It has been found that Trump referred to strong language and war metaphors to defend himself and his point of view, to shape Americans' thoughts and views, or to attack other countries or institutions. Several conceptual metaphors, including Covid-19 is a) an invisible enemy, b) a foreign enemy, c) a dangerous threat, and d) a global battle, were commonly used. The data analysis shows that Trump has a linguistic mastery of eloquent and persuasive devices in political discourse which permitted him to make a shift in Americans' thoughts and opinions. For future research, the current paper suggests investigating Trump's paralinguistic features in speeches, such as body language, facial expressions, tone and pitch of voice, eye movements, and hand gestures.
\end{abstract}

Keywords: Dysphemism; Metaphor; Discourse Analysis; Covid-19; Donald Trump

\section{INTRODUCTION}

Language is a form of social practice used for influencing, persuading, and shaping people's views and attitudes. It is a communicative way for describing something, convincing someone, giving promise, making compliment and other social goals (Olimat, 2018; 2019a; 2019b). Thus, it is very important to have a better understanding of language use, varieties, patterns, and functions in speeches and interactions particularly in the period of critical situations and crises. Corona Virus Disease 2019 (henceforth Covid-19) is an ongoing danger affecting all nations and people resulting in societal distance, financial problems, political and economic consequences, public health emergencies, and loss of lives. Presidents and politicians attempt to respond to Covid-19 pandemic in an unprecedented way. They have commonly addressed speeches and daily briefings about precautionary measures and plans formulated to reduce the global threat of the virus and make their fellow countrymen feel secure at such a difficult time. Therefore, televisions, newspapers, and social media channels remain dominant resources of breaking news in the era of Covid-19.

The significance of this research stems from Trump's position as the president of the greatest country in the world. His speeches are not only addressed in front of the Americans, but they are also broadcasted and viewed by all people across different means of mass media around the world. Trump's character is an issue of debate and division in media. He has the tendency to make a big impression when using social media platforms, replying to politicians or speaking to journalists. Because of his eloquence and command of language, Trump is considered an exceptional president and strong leader in the history of the U.S. He is famous for the power of his passionate words and the diversity of language resources which motivate minds and beliefs of his audience. Dochy (2018) described him as an unusual person who is "consistently breaking taboos of conventional political speech" (p. 9). Thus, his choice of 
words and phrases is a fertile area of research interests for academics. Many linguists have explored different linguistic aspects in Trump's use of social media (Enli, 2017; Ott, 2017). Moreover, figurative language and rhetorical devices used in Trump's discourse have received due attention in the area of political discourse analysis (Amine, 2017; Ali, 2018; Dochy, 2018). Similarly, the current research attempts to investigate Trump's use of dysphemistic expressions in his daily briefings on Covid-19 pandemic.

The present work is organised as follows. Firstly, a background to the study is provided. After that, statement of the problem and the research aims are clearly explained. A brief account of past studies carried out on the use of linguistic aspects for the representation of infectious diseases, such as Ebola, SARS, MERS, and H1N1, is introduced. Next, an explanation of the adopted theoretical framework in the current research is outlined. Then a description of the data collection and analysis is given. An analysis of a selected sample of dysphemistic expressions used in Trump's speeches is made according to the proposed theoretical paradigm. Finally, concluding remarks, key findings, and implications for future research are reported.

\section{PROBLEM STATEMENT AND RESEARCH OBJECTIVES}

Generally, the linguistic exploration of dysphemism in language is still very modest for sociocultural restrictions and taboos. Compared to other text types, political discourse has a large proportion or density of dysphemistic expressions addressing complex and controversial issues. This shows the extent of the serious need for a systematic linguistic investigation of the feature of dysphemism in politics. In addition, dysphemism in political discourse as a rhetorical and aesthetic device has not been given due consideration by scholars of language studies. Thus, the present study comes up with an analytical investigation of certain dysphemistic expressions used by Trump in daily briefings to his fellow Americans on the U.S battle against Covid-19 pandemic. According to popular databases, such as Elsevier coronavirus centre, Scopus, and Clarivate, the majority of researchers recently dealt with Covid-19 from a scientific or medical point of view focusing on public health guidance, symptoms and infection, treatment and vaccines, drug discovery, and other clinical information. However, to date no study has examined the feature of metaphoric dysphemism in Trump's Covid-19 speeches from a linguistic perspective. Thus, a critical-political discourse analysis of a sample of Trump's speeches with dysphemistic terms on Covid-19 seems to be a worthy enterprise.

Amine (2017) argued that "Trump particularly has a specific use of language" (p. 53). In particular, Trump's use of language and his fierce oratory against the threat of Covid-19 have sparked outpourings of linguistic commentary and analyses from my point of view. Thus, the current research examines dysphemistic terms and techniques used in Trump's discourses for dealing with Covid-19 pandemic. It aims to analyse the interpretation and intentions beyond using offensive expressions in Trump's Covid-19 speeches for the U.S citizens in particular and the international community in general. It also measures the degree of effectiveness of Trump's language choice of dysphemisms manipulated in Covid-19 speeches. To achieve these goals, I relied on the theories of Critical-political Discourse Analysis initiated by Van Dijk (1997; 2001) and Conceptual Metaphor developed by Lakoff and Johnson (1980), and the concept of dysphemism proposed by Allan and Burridge (2006).

\section{LITERATURE REVIEW}

This part provides a brief description of past studies on the use of linguistic strategies and aspects for the representation of contemporary infectious diseases, such as Ebola, SARS, 
MERS, and H1N1. Patrick and Nerlich (2005) examined metaphoric language devoted to the global 2003 SARS pandemic in five daily newspapers in the UK, namely, The Mirror, The Guardian, The Sun, The Daily Telegraph, and Daily Mail. They found that political, cultural, social, and media factors played a significant influence in linguistic framing of SARS metaphors. They also found that the SARS media content relied mainly on a limited number of common metaphors. Although militaristic language is a basic characteristic of discourses of bioscience and disease, it was mostly absent in the SARS UK media coverage. They observed that the cognitive metaphor 'SARS as a killer' was frequently used to deal with the nature of SARS, its local and human effect, and individual reactions. They noticed that struggle metaphors were heavily used to represent human and economic influences of SARS.

Joye (2010) evaluated the news representation of the spring 2003 global SARS in two Belgian televisions, namely VRT and VTM based on Critical Discourse Analysis (CDA) by Fairclough, $(1992 ; 1995)$ and taxonomy of pity and news discourse by Chouliaraki (2006; 2008). The data analysis showed that proximity motivates the identification and feelings of compassion. Therefore, it played a vital role in categorising news discourse and the mediated regime of pity. The study revealed that the international news coverage of the crisis of SARS outbreak uncovered socio-cultural hierarchies amongst societies and danger-safety divisions amongst nations as well. It concluded that Western news media broadly showed a EuroAmerican-centred world order.

Angeli (2012) explored the significant function of the metaphors surrounding H1N1 and swine flu from a rhetorical point of view. She thematically classified the relevant metaphors mentioned in electronic resources, such as articles, blogs, and websites. She suggested a rhetorical description of $\mathrm{H} 1 \mathrm{~N} 1$ and swine flu to allow health care recipients to be more familiar with how health concerns can be expressed in electronic media metaphors. Trčková (2015) conducted a study on the conceptual metaphorisation of Ebola disease in two American newspapers with liberal tendencies, namely, The New York Daily News and The New York Times. He applied Critical Discourse Analysis (CDA) and the Cognitive Theory of Metaphor. It has been found that the two newspapers relied mainly on popular cognitive metaphors, such as Ebola is war, Ebola is an animate/human being, and Ebola is a natural catastrophe. He indicated that both newspapers totally failed to represent the infected people in Africa as sovereign agents. The study concluded that the military metaphoric representation of Ebola rarely characterised African patients as fighters even though it tackled the negative effect of the virus.

Shin (2016) attempted to evaluate to what extent the social cognition and ideology of speakers may affect in the choice of MERS metaphors in South Korea. He also attempted to determine universal and specific metaphorical representations of MERS based on previous research works carried out on SARS. To achieve these goals, he analysed MERS titles and headlines in five popular newspapers in South Korea. He addressed the metaphorical frame of the social danger of the MERS virus based on social conditions and ideological factors of media in South Korea. The study indicated that MERS metaphors in the selected newspapers were not too different from other metaphors used to describe severe contemporary infectious diseases. It concluded that political and ideological attitudes were influential factors in the choice of metaphors.

Similarly, Jeon and Yu (2016) examined MERS metaphorical devices used in Korean news reporting. They aimed to create a comprehensive list of MERS-related metaphorical expressions. They also tried to interpret ideological information reflected in MERS metaphors in two broadcasting Korean channels, namely, KBS and JTBC. They produced a broad corpus of common metaphorical examples, such as MERS as war, MERS as wave, MERS as a living thing, and MERS as a thing. The study disclosed that the ideology of the two channels played an influential role in the choice of metaphoric language. For example, KBS used MERS as 
wave to clarify the aftermath of MERS as something not dangerous in contrast to JTBC which used the same metaphor to demonstrate that the aftermath of MERS had negative influences on economy.

Balteiro (2017) researched Ebola metaphorical expressions and their intentions in scientific discourse. Some articles dealing with Ebola-related themes released in Scientific American were analysed. She found that Ebola as war and recovery as a road were the most commonly used metaphorical instances in the selected discourse. She pointed out that metaphoric expressions were derived from culturally noticeable things or experiences to permit specialists, medical practitioners, and reporters to accurately exchange Ebola-related information with non-experts in an appropriate way. She concluded that metaphorisation was an effective approach for individuals and communities to understand health situations, concepts, or topics devoted to Ebola.

Tan et al. (2020) examined a group of recent Covid-19 research papers by different scholars with corpus-based, comparative textual, and content analyses at the macro- and microlinguistic levels. The study revealed that scholars from different parts of the world explored, at the macro level, several ways by which government institutions and agencies can communicate with the public about Covid-19 global pandemic. At the micro level, other scholars examined certain corpora with lexical, semantic, and discourse information of personal stories and photos to capture lessons from human experience. It has been found that some research studies can help readers to understand human communication at a personal level as well as beneficial measures applied by certain governments to reduce the effect of Covid-19 pandemic, while other research studies can help writers, researchers, and authorities in specific areas by clarifying structures of moves at a governmental level for further discourse analysis.

More recently, Olimat (2020) explored the Jordanians' use of euphemistic and dysphemistic expressions for dealing with Covid-19 pandemic. Therefore, he designed a comprehensive questionnaire including closed-ended and open-ended questions, and then it was distributed to a sample of 200 Jordanian speakers. From a sociolinguistic point of view, the collected data was analysed according to the theories of euphemism and dysphemism by Allan and Burridge (1991; 2006) and Warren (1992) and Conceptual Metaphor by Lakoff and Johnson (1980). It has been found that the Jordanian respondents adopted several euphemistic strategies when talking about Covid-19 pandemic, such as scientific abbreviations, metaphors, medical terms, and shift from Arabic into English. The data analysis showed that the participants rarely used dysphemistic terms while speaking about Covid-19. Olimat concluded that the understanding of euphemistic and dysphemistic tendencies and the paralinguistic features of Jordanian speakers during global crises should be further investigated.

\section{TOWARDS A THEORETICAL PARADIGM OF TRUMP'S DYSPHEMISTIC USE OF COVID-19}

Political discourse plays a critical role in organising, developing, and managing societies. According to Dylgjeri (2017), political discourse is "a means of establishing and maintaining social relationships, expressing feelings, and selling ideas, policies, and political projects in any society" (p. 20). Crespo-Fernández (2013) defined political discourse as a "form of political action which does ideological work, exerts social control, and legitimates power in the socio-political context." (p. 316). It is fully loaded by figurative expressions and linguistic strategies employed for specific purposes. Politicians generally aim to persuade the public and reshape their thoughts about certain situations or events. In this sense, Crespo-Fernández (2013, p. 311) indicated that politicians use powerful words in their speeches as weapons for achieving ideological purposes and making the public believe something in an ostensive way. Political 
leaders often refer to different kinds of rhetorical utterances and figures of speeches with varied semantic, syntactic and stylistic constructions, i.e. dysphemism, for attaining several goals, such as supporting a certain party, persuading the public, arguing about a political issue, releasing from responsibility, and attacking enemies or opponents.

Political discourse relies mainly on the heavy use of rhetorical, figurative, and persuasive expressions. Politicians resort to such devices and strategies in order to constitute the public attitudes and affect their thoughts and opinions. Van Dijk (2001) viewed critical discourse analysis (CDA) as a "type of discourse analytical research that primarily studies the way social power abuse, dominance, and inequality are enacted, reproduced, and resisted by text and talk in the social and political context." (p. 352). It seems that Critical Discourse Analysis (CDA) basically handles power and dominance aspects, social problems, political issues in written or spoken communicative situations. Van Dijk indicated that the Criticalpolitical Discourse Analysis evaluates the process of reproducing "political power, power abuse or domination through political discourse." (1997, p. 11). Crespo-Fernández (2013) indicated that this approach investigates "the strategic use of linguistic patterns or keywords for achieving specific political aims" (p. 316). Language is an influential way for expressing politicians' goals and understanding people's socio-cultural behaviours. Thus, Critical-political Discourse Analysis is used to tackle persuasive and communicative expressions by powerful speakers. At the micro-level, the current research attempts to assess Trump's linguistic capacity, powerful verbal discourse, and techniques of persuading and influencing his audience on Covid-19 pandemic. It explores how dysphemistic items deliberately used by Trump for emphasising political attitudes, manipulating opposite perspectives, manufacturing public consent, or legitimating political views. At the macro-level, it attempts to evaluate the power, intention, dominance, and inequality resulted from devoting dysphemistic expressions to deal with Covid-19. To conclude, the research aims to examine how Trump managed to exert his power and authority to persuade and influence his audience through a critical evaluation and systematic analysis of selected dysphemistic expressions employed in his Covid-19 speeches.

Lakoff and Johnson (1980) initiated Conceptual Metaphor theory which indicates that metaphor is a cognitive mechanism by which speakers can represent the reality in an indirect way. It suggests that one experimental domain is partially mapped onto a different domain which is constructed and perceived based on the first one. The domain that is mapped is named the source, and the domain that is mapped onto is named the target. Crespo-Fernández (2013, p. 317) claimed that metaphor is an effective linguistic strategy of creating, organising, and understanding the real world. Charteris-Black (2005), regarded metaphor as a pragmatic way to "identify the intentions and ideologies underlying language use." (p. 26). According to Lakoff and Johnson, metaphoric expressions function for either highlighting or hiding. Metaphor enables people to understand a specific feature of a certain concept in terms of another concept, but this may hide other features of the concept. In case of dysphemistic cases, the source domain, i.e. dysphemism, is mapped systematically to the target domain, i.e. orthophemism or euphemism. Therefore, some offensive, taboo or negative aspects of the target domain are emphasised or highlighted, while normal, positive, convenient, or neutral features are hidden or disregarded.

Dysphemism is a common linguistic feature in political discourse used by politicians for handling controversial issues or criticising their opponents indirectly. This indicates that the unpleasantness or sensitivity of serious topics could motivate politicians to resort to disagreeable terms for misleading the public or distorting the reality. Allan and Burridge (2006) defined dysphemism as "a word or phrase with connotations that are offensive either about the denotatum and/or to people addressed or overhearing the utterance" (p. 31). They described dysphemism as a 'speaking offensively' strategy. Crespo-Fernández (2015) viewed dysphemism as "the process whereby the most pejorative traits of the taboo are highlighted 
with an offensive aim to the addressee or to the concept itself." (p. 2). Crespo-Fernández (2007; 2013) claimed that dysphemism is a persuasive approach of manipulating ideological attitudes and social control in political discourse. In brief, politicians often refer to offensive or tough expressions in their speeches for serving several political purposes, such as blaming, accusing, and influencing. For a long time, political discourse has been a central domain for linguists who have drawn their attention upon the language use of politicians, figures, and diplomates. This research work investigates potential interpretations and enthusiasm of Trump's use of dysphemistic expressions in selected daily speeches on Covid-19 pandemic.

\section{METHODOLOGY}

\section{DATA COLLECTION}

A sample of dysphemistic expressions was extracted from Trump's speeches devoted to Covid19 pandemic over a crucial week of $11^{\text {th }}$ of March 2020 till $18^{\text {th }}$ of March 2020. Trump's speeches addressed in this period were chosen for major reasons. The World Health Organisation (WHO) declared Covid-19 as a global pandemic on the $11^{\text {th }}$ of March 2020, and, therefore, the majority of countries worldwide requested their citizens to quarantine at home and practice physical and social distancing. During this period, the epidemiological situation in the U.S became more fraught especially when the confirmed infectious cases and registered deaths started to double every day (WHO, 2020; CDC, 2020). As a result, stock markets, finance, and banks continued to rapidly decline, and many national events in various U.S states were cancelled or postponed. Hence, Trump received heavy criticism in the media and politics since he ignored experts and administration officials' warnings of the serious threat and the sharp spread of Covid-19 virus in the early phases. This forced him to change his tone and declare a national emergency and backtracked on most of his previous decisions. The data was mainly collected from either recorded videos or scripts of Trump's speeches based on the observational approach of his language use. In more detail, the selected sample of dysphemistic expressions was taken from two popular American Newspapers, mainly The Washington Post and The New York Times, and two major American broadcast television networks, mainly BBC America and CNN. Taking-note technique was adopted while watching recorded videos of Trump's speeches or reading his transcripts. The data collection was confined to Trump's language dealing with the theme of Covid-19 pandemic.

\section{DATA ANALYSIS}

The collected sample of Trump's dysphemisms was analysed from different linguistic dimensions. Firstly, the selected sample of dysphemistic expressions were interpreted and explained based on the denotative and connotative meanings of vocabularies in dictionary. To achieve this goal, the researcher relied on Almaany online dictionary (2010) which provides several meanings and usages of English terminologies in various genres and texts. Secondly, possible interpretations of Trump's intention of using the selected dysphemistic expressions were clarified and investigated according to the theoretical framework of Critical-Political Discourse Analysis proposed by Van Dijk (1997; 2001). Thirdly, the selected sample of dysphemistic terms was analysed according to the Conceptual Metaphor theory introduced by Lakoff and Johnson (1980), and Allan and Burridge's concept of dysphemism (2006). Due to the limited scope of the research, the time and space restrictions, and the reliance on a sample of relatively small dysphemistic data extracted from a number of Trump's speeches, it was not permitted to report the main results in quantitative terms. Instead of that, the data analysis of the study was principally qualitative depending on the tradition of rhetoricians, discourse 
analysts and linguists who always research a small number of examples covering a certain linguistic feature. However, the selected corpus of dysphemistic utterances can give a comprehensive view and deep insights into the nature of Trump's eloquence and language use at a critical time of his presidency.

\section{FINDINGS AND DISCUSSION}

The data analysis shows that Trump explicitly used a great number of dysphemistic expressions with pejorative connotations in his daily Covid-19 speeches for different goals, such as metaphorising Covid-19 pandemic, attacking China where the virus is thought to have first initiated, and defending political decisions on the U.S protective measures to reduce the global threat of Covid-19.

Example 1: "This is the most aggressive and comprehensive effort to confront a foreign virus in modern history”. (March 11, 2020)

The word 'foreign' is used to indicate that something is originating in another place or part of the world. It has several synonymous words, such as unknown, strange, abroad, external, and outside (Almaany, 2010). Characterising Covid-19 as a 'foreign virus' by Trump is not a simple rhetorical flourish. On the contrary, he claims that Covid-19 is a foreign invader originated in China, which is a major strategic competitor of the U.S. He intentionally used this lexical item on the same day of the official announcement of Covid-19 as a global pandemic by the WHO which is a widely accepted public health authority. The WHO officially labelled it 'Covid-19' to avoid geographic references assigning blame to a particular region. I argue that viruses do not know borders, ethnicity, or nationalities, so the use of such a political expression may result in a weakness of making constructive efforts and international collaboration for beating the virus and strengthening the global public health security. It is very significant, therefore, for politicians to be more careful in the language choice.

According to Van Dijk (1997; 2001), Critical-political Discourse Analysis is a linguistic tool showing a great part of the politician's ideology, identity, purposes, attitudes, and position. Therefore, casting Covid-19 as 'a foreign virus' gives an evidence that Trump realised that the disease has become a large-scale and dangerous threat to the U.S after he downplayed its likely consequences and seriousness at the early stages when he dismissed the scientists' warnings and presented the disease as a minor nuisance. He may also resort to this strange description since there were no scientific facts about the virus in terms of resource, modes of transmission, common symptoms, and other scientific features. At the beginning of the global Covid-19 spread, the true death rate worldwide was still obscure, and the international community had no idea outbreak would be this bad.

Trump may use the adjective 'foreign' for emphasising his own idea that China is responsible for the global spread of Covid-19. He adopted an indirect or circumlocutory speech where many words, instead of fewer ones, were applied for the purpose of being more vague, i.e. periphrasis. Mugair $(2014$, p. 266) indicated that politicians focus primarily on vague language to extend the scope of information. Periphrasis is a major linguistic approach used for producing dysphemistic expressions by relying on more words to express a certain idea. It is a common device involving roundabout expressions adopted by politicians for generating dysphemistic utterances to disguise their intentions, to cover up the truth, or to deal with a sensitive or offensive topic indirectly. Circumlocutory language is broadly used by political leaders to uphold civility and avoid impertinence (Allan and Burridge, 1991; Enright, 2004; Crespo-Fernández, 2007). 
Lakoff and Johnson (1980) claimed that conceptual metaphors are adopted to shape the world view by highlighting or hiding specific aspects of a sensitive theme. The use of 'foreign virus' implies that the U.S is a body encountering an unknown or external danger identified as 'foreign'. According to Musolff (2016), the metaphor 'nation-as-a-body' suggests that the nation state or its institutions can be conceptualised by "functionally motivated analogies to the whole and parts of a human body" (p. 118). Trump associated the Covid-19 virus with foreignness to externalise the responsibilities of fighting this global pandemic to the international community. It can be concluded that Trump obviously used the metaphoric language of warfare, i.e. Covid-19 is an enemy, in his speeches to combat the dangerous threat since military expressions may help in increasing Americans' morale.

Example 2: "I am confident that by counting and continuing to take these tough measures, we will significantly reduce the threat to our citizens, and we will ultimately and expeditiously defeat this virus.". (March 11, 2020)

The word 'threat' has several meanings, including harm, pain, injury, damage, or other hostile actions. It also means a warning that something unpleasant or violent is impending (Almaany, 2010). Mugair (2014, p. 264) indicated that the word 'threat' in political texts often suggests offensive and pejorative implications, e.g. NATO has a deterrent against the Russian threat. Van Dijk $(1997 ; 2001)$ claimed that the ideology of political leaders, such as political and social beliefs, can be clearly shown in political discourse analysis. In this context, Trump received heavy criticism on social media since he ignored the potential threat of Covid-19 seriously enough. He used this dysphemistic term to assert that the American citizens are currently battling a deadly virus leading to dreadful future to them. Nevertheless, he sought to persuade his fellow countrymen that they will be actually capable of reducing its effect and reach and, hence, defeating the virus.

Metaphorically speaking, Trump described Covid-19 as a dangerous threat which does not qualify as military since it is an unforeseen danger which may last for a long time. Conceptual Metaphor theory by Lakoff and Johnson (1980) indicates that speakers can shape people's understanding and attitudes towards the world through emphasising neutral or less negative features of a certain concept, while the potential offensive features are overlooked. Based on that, Trump attempted to highlight the less negative consequences of the virus to Americans, i.e. economic or financial effects, whereas the substantial number of confirmed infectious cases and resulting deaths in the U.S was disregarded or minimised as inevitable. The hazardous level of the rapid spread and extreme severity of Covid-19 pandemic in the U.S was hidden as well. It can be concluded that the cognitive metaphor 'Covid-19 is a threat' is obviously adopted in this speech.

Example 3: "No matter where you look, this is something-it's an invisible enemy. I just say this: We have an invisible enemy." (March 16, 2020)

Trump frequently used the adjective 'invisible' in the $16^{\text {th }}$ March daily briefing to describe Covid-19 as something impossible to be seen by the eye. The word 'invisible' has several synonyms, such as unseeable, hidden, unnoticeable, obscure, undetectable, covert, and concealed (Almaany, 2010). From a scientific perspective, viruses cannot be seen by the naked eye. According to Van Dijk (1997; 2001), one of the crucial elements of Critical-political Discourse Analysis is understanding the nature of social power, dominance, and mostly political language of leaders. Trump used this lexical account to ascribe the virus into a sentient thing with an evil intention upon human beings. Trump' rhetorical shift from 'foreign virus' to 'invisible enemy' is an acknowledgment of the severity of the global pandemic and the hidden 
menace. Labelling Covid-19 as an 'invisible enemy' is a political strategy to blunt criticism for its rapid spread in the U.S and push blame onto a foreign power, i.e. China. At the early stages, Trump dismissed the global health threat averting his eyes to the coming danger, but his use of this expression indicates that Americans cannot be responsible for fighting against an invisible, mysterious, frightening, or unknowable thing.

Metaphorisation or conceptualisation is a linguistic approach allowing speakers to discuss a complex social problem, a sensitive issue, or an abstract information in terms of comparatively simple and more concrete information (Lakoff and Johnson, 1980). The use of war metaphors, such as 'war on crime', 'war on drugs', 'war on poverty', 'war on cancer', is a universal linguistic aspect in public discourse. According to Alexandrescu (2014) and Coleman (2013), war metaphors in political texts primarily function to evoke a sense of fear. Therefore, Trump repeatedly mentioned this type of metaphors in his daily briefings to shape his fellow countrymen's views and knowledge towards the virus. According to this metaphoric use, the U.S is engaged in a great battle against an unseen enemy which threatens to kill American people and destroy the U.S nation. He attempted to deemphasise possible painful aspects of the war against Covid-19, such as death cases, infected people, economic breakdown, while he attempted to focus on positive aspects of the war, such as great victory. He wanted to motivate the public attention and support by making American citizens believe they are now soldiers in a real conflict with an 'invisible enemy'. The metaphoric use of 'invisible enemy' is a verbal sign of hosting hardships and mobilising the U.S and its citizens. Based on this military symbolism, Trump positioned himself as a 'wartime president' against an existential threat.

Similarly, Health Secretary of Britain reported that his country is fighting a "war against an invisible killer" (Telegraph, March 16, 2020). Also, Andrew Cuomo, Governor of New York, stated that "the soldiers in this fight are our health care professionals. It's the doctors, it's the nurses, it's the people who are working in the hospitals, it's the aids. They are the soldiers who are fighting this battle for us." (https://www.rev.com, March 30, 2020). Trump may forget that defeating such an unnoticeable virus does not only require local efforts and military power, but it also requires a medical and international collaboration of the production of basic health supplies and effective vaccines. Describing Covid-19 as an 'invisible enemy' is a linguistic indication of highlighting dysphemistic features and unpleasant consequences of the disease. It can be concluded that the conceptual metaphor 'Covid-19 is an enemy' is applied in this dysphemistic example.

Example 4: "Ifelt it was a pandemic long before it was called a pandemic." (March 17, 2020)

The word 'pandemic' is used in language to describe a severe disease occurring throughout a whole region or even throughout the world. In other words, a deadly disease is predominant over a wide geographical area or exists everywhere over the universe. There are some differences between 'epidemic' and 'pandemic'. Epidemic is used to account an unexpected increase in the occurrence of a disease typically limited to a less local area or a specific community of people. If the outbreak of the disease broadens further and touches an exceptionally considerable part of the people, it is called as a pandemic (Almaany, 2010). Historically, a number of pandemics occurred throughout the world. The plague, the Black Death, spread across Asia and Europe in the $14^{\text {th }}$ century. The Spanish flu of 1918/19 affected a high proportion of the population globally. In 2009, the H1N1 pandemic has spread across a wide geographic area over the world. Nowadays, the word 'pandemic' is frequently used to deal with Covid-19 which has been spreading worldwide since December 2019 resulting in millions of infected people and thousands of registered death cases. 
In this speech, Trump indicates that he realised that Covid-19 was a global pandemic before the WHO labelled it as a pandemic. Critical-political Discourse Analysis suggests that the choice of language by politicians and officials reflects their intentions, ideology, and thought (Van Dijk, 1997; 2001). Trump's use of the word 'pandemic' is an obvious linguistic indication that this virus has a higher risk of transmission and a sharp spread in the vast majority of the world countries. Therefore, nations, institutions, and people are required to collaborate for fighting or, at least, impeding this global enemy. He may intend to shift Americans' views away from the government preparedness to the public's responsibility by using such a word with offensive associations. He resorted to strong language to maximise the serious threat of Covid-19 after the WHO declared it as a pandemic although he minimised its disastrous effects for weeks at the beginning of the global outbreak. Trump used the word 'pandemic' to excuse his failure of responding quickly enough to contain the spread in the U.S expressing his hope that the U.S will be able to suppress and control the coronavirus outbreak.

According to Lakoff and Johnson (1980), metaphor focuses on a clearly understandable identity or concept of a specific topic to gain a deeper understanding of a lesser known element of another topic. It is one of the most necessarily persuasive and beneficial devices used by politicians in discourse. Therefore, it would be wise for people to expand their thinking and awareness of figurative language, i.e. metaphors, expressed by politicians. When the WHO declared Covid-19 as a pandemic, Trump represented it as a threatening danger of the whole world using the world 'pandemic' for the first time. Metaphorically speaking, Trump identified Covid-19 as an enemy trying to bear the responsibility of the virus not on internal errors but on external factors, such as the weakness of the WHO and the Chinese authorities. By using this metaphorical expression, Trump sought to distract his fellow Americans away from the inadequacy of the U.S health system. He strived to depict Covid-19 as a global challenge which does not respect the frontiers and requires an international collaboration on different levels including politics, economy, health, etc. He aimed to position himself as a president of war looking for more popularity and public support in times of global crises. Therefore, he emphasised that the U.S is currently in a continuous battle to safeguard the lives of American citizens. To conclude, the metaphor 'Covid-19 is a battle' is employed in this dysphemistic example.

Example 5: "I always treated the Chinese virus very seriously, and have done a very good job from the beginning, including my very early decision to close the 'borders' from China against the wishes of almost all." (March 18, 2020)

People are socially categorised according to their origin, i.e. birthplace, although terms tied to ethnic background and race are potential spaces of controversy. Products are sometimes described according to where they are made. For example, Swiss Made is a label often associated with watches made or assembled in Switzerland. In Arabic culture, people are called according to where they come from. Trump frequently called Covid-19 as the 'Chinese virus' in his daily speeches. He attempted to represent China as the main hotspot of the virus, and hence responsible for this global pandemic. The WHO officially labelled the disease 'Covid$19^{\prime}$ to avoid stigmatising Chinese communities or individuals. Despite of a severe criticism directed by the WHO, and Chinese and Asian Americans, Trump insisted that he did not use offensive language since this disease came from China. He defended that this pejorative term was merely a political response to Chinse officials who already claimed that the virus is a biological weapon deployed by the U.S military.

Van Dijk indicated that critical-political discourse analysts often evaluate specific linguistic examples of injustice, inequality, racism and discrimination, social abuse, suffering, and prejudice in political communication (1997; 2001). Trump's strong language could 
establish social divisiveness and xenophobia leading to a noticeable incline in hate crimes and physical abuses against Asian Americans in general and Chinse Americans in particular. The general public speakers, experts, and officials used to adopt scientific or appropriate names, including corona, coronavirus, coronavirus 2019, SARS-CoV-2, or Covid-19. Nonetheless, Trump's nasty terminology allowed U.S officials to excessively use the 'Chinese virus' in social media channels and television interviews. In addition, some U.S politicians labelled it as 'Wuhan virus', a city in the middle of China where the virus is thought to have first originated. Other political leaders in the U.S called it as ' $k u n g$ flue' based on the fact that Covid19 was identified in the land of Kung $\mathrm{Fu}$ which is one of the most widely known Chinese martial arts. These officials argued that diseases were historically named according to where they came from, such as Spanish Flu, West Nile Virus, Zika, and Ebola.

Metaphors are indispensable in language since they give speakers an effective opportunity to understand the world. Based on the fact that metaphor is a pervasive characteristic of political rhetoric, Trump personified the pandemic by using 'Chinese virus'. Personification as a metaphorical approach implies to understand a strange thing, i.e. the virus, by using a familiar term, i.e. location or nationality. Lakoff and Johnson (1980) claimed that metaphors are usually used to shape the global view by highlighting or hiding certain aspects of a certain idea. The use of 'Chinese virus' indicates that the U.S is a body facing an external or foreign threat. The nation-as-a-body is a conceptual metaphor commonly lexicalised in English and still plays an influential role in present-day public and political discourses (Musolff, 2014; Kövecses, 2005; 2002; Lakoff and Turner, 1989). Trump linked the infection, i.e. Covid-19, with an ethnicity or identity, i.e. China, intending to release himself from domestic responsibilities and to blame an external factor for this foreign enemy. It can be concluded that Trump's metaphorical use of language, i.e. Covid-19 is an enemy and nation$a s-a-b o d y$, acquired a dysphemistic status owing to its offensiveness to Chinese people's sentiments and beliefs.

\section{CONCLUSION AND IMPLICATIONS FOR FUTURE RESEARCH}

Political discourse is rich in metaphoric dysphemistic expressions used by politicians to describe the reality of global incidences, e.g. disease spread, in an indirect way. Therefore, the present research provides an analytical investigation to what extent politicians can adopt or accept some dysphemistic practices and terms. It presents a rhetorical analysis of Trump's discourse by examining Covid-19 metaphoric dysphemisms reflected in certain speeches in a critical period. It has been found that Trump resorted to strong language with more violent expressions, more prone to insults, and more distasteful and discriminatory imagery. He used various military expressions and conceptual metaphors to emphasise his points of view or intentions, such as Covid-19 is a) an invisible enemy, $b$ ) a foreign enemy, c) a dangerous threat, and d) a global battle. The cognitive metaphor 'nation-as-a-body' was also applied in his daily speeches. He always turned around war concepts and metaphors of legitimisation of military violence to shape Americans' thoughts about how they should fight the Covid-19 virus.

Trump's employment of war metaphors for Covid-19 pandemic may reduce the complexity of the problem, but it may help Americans stay more focused on fighting, aggression, and offensiveness, not on caring, supporting or safeguarding themselves. The data analysis shows Trump's mastery of language and eloquence and persuasive capacity in political discourse which have considerable influences in changing Americans' views and attitudes. For future research directions, researchers are recommended to explore extralinguistic features of Trump's character, such as body language, facial expressions, tone and pitch of voice, eye movements, and hand gestures; and to study the effectiveness of such paralinguistic features 
upon the audience. Future research also includes examining a larger text corpus of contextually Trump's use of dysphemistic and metaphoric language.

\section{REFERENCES}

Alexandrescu, L. (2014). Mephedrone, assassin of youth: the rhetoric of fear in contemporary drug scares. Crime, Media, Culture. 10(1), 23-37.

Ali, M. (2018). Political diplomatic tone in presidential inauguration address of the USA President Donald Trump: a critical discourse analysis. M.A thesis, Alandalus University, Republic of Yemen.

Allan, K. \& Burridge, K. (1991). Euphemism and dysphemism. Language used as shield and weapon. Oxford: Oxford University Press.

Allan, K. \& Burridge, K. (2006). Forbidden words: taboo and the censoring of language. Cambridge: Cambridge University Press.

Amine, D. (2017). Interpretation of discourse markers in Trump's political speeches. Case study: The function of the markers so, anyway, you know in Trump's selected speeches. M.A thesis, University of Mostaganem, Algeria.

Angeli, E. (2012). Metaphors in the rhetoric of pandemic flu: Electronic media coverage of H1N1 and swine flu. Journal of Technical Writing and Communication. 42(3), 203-222.

Balteiro, I. (2017). Metaphor in Ebola's popularised scientific discourse. Ibérica. 34, 209-230.

Charteris-Black, J. (2005). Politicians and rhetoric. The persuasive power of metaphor. Basingstoke \& New York: Palgrave MacMillan.

Centers for Disease Control and Prevention (CDC). (2020). United States COVID-19 cases and deaths by state. Retrieved from https://covid.cdc.gov/covid-data-tracker/\#cases.

Coleman, M. P. (2013). War on cancer and the influence of the medical-industrial complex. Journal of Cancer Policy. 1(3-4), e31-e34.

Crespo-Fernández, E. (2007). El eufemismo y el disfemismo. Procesos de manipulación del tabú en el lenguaje literario inglés Alicante: Universidad.

Crespo-Fernández, E. (2013). Words as weapons for mass persuasion: dysphemism in Churchill's wartime speeches. Text \& Talk. 33(3), 311-330.

Crespo-Fernández, E. (2015). Sex in language: Euphemistic and dysphemistic metaphors in internet forums. London and New York: Bloomsbury

Dochy, A. (2018). Speaking “transgressive truth": Assessing the political extremism of Donald Trump's campaign discourse during the 2015/2016 US presidential pre-primaries and primaries. M.A thesis, Utrecht University, Netherlands.

Dylgjeri, A. (2017). Analysis of speech acts in political speeches. European Journal of Social Sciences Studies. 2(2), 19-26.

Enli, G. S. (2017). Twitter as arena for the authentic outsider: Exploring the social media campaigns of Trump and Clinton in the 2016 US presidential election. European Journal of Communication. 32(1), 50-61.

Enright, D. (2004). In other words. London: Michael O’Mara Books Limited.

Jeon, H. \& Yu, H. (2016). Metaphor and ideological implications for MERS. Korean Studies. 72, 99-225.

Joye, S. (2010). News discourses on distant suffering: A critical discourse analysis of the 2003 SARS outbreak. Discourse \& Society. 21(5), 586-601.

Kövecses, Z. (2002). Metaphor. A practical introduction. Oxford: Oxford: University Press.

Kövecses, Z. (2005). Metaphor in culture: Universality and variation. Cambridge: Cambridge University Press.

Lakoff, G. \& Johnson, M. (1980). Metaphors we live by. Chicago: University of Chicago Press.

Lakoff, G. \& Turner, M. (1989). More than cool reason. a field guide to poetic metaphor. Chicago: University of Chicago Press.

Mugair, S. K. (2014). A comparative study of euphemism and dysphemism in English and Arabic with special reference to political discourse. Journal of Advances in Linguistics. 4(1), 259-268.

Musolff, A. (2014). The metaphor of the "body politic" across languages and cultures. In Polzenhagen, F. Kövecses, Z. Vogelbacher, S. \& Kleinke, S. (EDs). Cognitive explorations into metaphor and metonymy. (pp. 87-99). Frankfurt: Peter Lang.

Musolff, A. (2016). Political metaphor analysis: Discourse and scenarios. London: Bloomsbury Publishing.

Olimat, S. N. (2018). Developing a model for translating euphemism in the Qur'an: An intratextual- and contextual-based approach. Advances in Language and Literary Studies. 9(6), 101-111.

Olimat, S. N. (2019a). Euphemism in the Qur'an: Corpus-based linguistic analysis and intratextual- and contextual-based translation. Ph.D. Thesis, University of Leeds, UK.

Olimat, S. N. (2019b). Euphemism in the Qur'an: A corpus-based linguistic approach. International Journal of Computational Linguistics (IJCL). 10(2), 16-32. 
Olimat, S. N. (2020). COVID-19 pandemic: Euphemism and dysphemism in Jordanian Arabic. GEMA Online ${ }^{\circledR}$ Journal of Language Studies. 20(3), 268-290.

Ott, B. L. (2017). The age of Twitter: Donald J. Trump and the politics of debasement. Critical Studies in Media Communication. 34(1), 59-68.

Patrick, W. \& Nerlich, B. (2005). Disease metaphors in new epidemics: The UK media framing of the 2003 SARS epidemic. Social Science \& Medicine. 60, 2629-2639.

Shin, J. (2016). Metaphorical analogies for 'MERS' in Korean newspaper headlines. Discourse and Cognition. 23(2), 51-19.

Tan, K.H., Woods, P., Azman, H., Abdullah, I. H., Hashim, R. S., Abdul Rahim, H., Idrus, M. M., Said, N. E. M., Lew, R., \& Kosem, I. (2020). COVID-19 insights and linguistic methods. 3L: The Southeast Asian Journal of English Language Studies. 26(2), 1-23

Trčková, D. (2015). Representations of Ebola and its victims in liberal American newspapers. Topics in Linguistics. 16, 29-41.

Van Dijk, T. A. (1997). What is political discourse analysis? In Blommaert, J. \& Bulcaen, C. (EDs.). Political linguistics. (pp. 11-52). Amsterdam: John Benjamins.

Van Dijk, T. A. (2001). Critical discourse analysis. In Schiffrin, D. Tannen, D. \& Hamilton, H. E. (EDs). The Handbook of Discourse Analysis (pp. 352-371). Oxford: Blackwell.

World Health Organisation (WHO). (2020). COVID-19 press briefing. Retrieved from https://www.who.int/emergencies/diseases/novel-coronavirus-2019.

https://www.telegraph.co.uk/politics/2020/03/16/coronavirus-cobra-meeting-boris-johnson-chris-whitty-patrick/ https://www.rev.com/blog/transcripts/governor-andrew-cuomo-new-york-covid-19-press-conference-transcriptmarch-30 